\title{
Еще один шанс для «Хельсинки снизу»? Возрождение правозащитных групп, связанных с ОБСЕ
}

Дмитрий Макаров*

\section{Аннотация}

Разное понимание государствами-участниками ОБСЕ ее роли вызвало раскол, причем главной жертвой этого кризиса стало ее человеческое измерение. Во время «холодной войны» хельсинкское движение поставило в центр Хельсинкского процесса права человека. Деятельность движения повлияла на международную политику и придала актуальность принципам прав человека. Однако в начале XXI в. движение пошло на спад, не сумев эффективно отреагировать на авторитарную реакцию, пострадав от «НПОизации» правозащитной деятельности и сосредоточив свое внимание на ЕС и Совете Европы. Несмотря на эти тенденции, в регионе ОБСЕ были примеры творческого и ориентированного на конкретные задачи транснационального сотрудничества. Опираясь на эти примеры, в данной статье показано, что ОБСЕ может стать более значимой организацией, если на первый план выйдет обновленное хельсинкское движение.

Ключевые слова

Хельсинкское движение, права человека, правозащитники, мобилизация граждан

Для цитирования этой публикации: Макаров Д. Еще один шанс для «Хельсинки снизу»? Возрождение правозащитных групп, связанных с ОБСЕ // ОБСЕ Insights 7/2021 — Баден-Баден: Номос, 2022. URL: https://doi.org/10.5771/9783748911463-07

\section{Введение}

Хельсинкское движение начиналось с мониторинговой деятельности, осуществлявшейся не связанными друг с другом группами граждан, но вскоре превратилось в вызвавшую резонанс транснациональную сеть организаций, добивавшихся соблюдения принципов прав человека. Хотя многие хельсинкские комитеты продолжают свою деятельность и сейчас, объединенное движение не дожило до XXI в. Еще одна

* Дмитрий Макаров, член Совета Московской Хельсинкской группы, orlovets@gmail.com 
волна активности, вдохновленная хельсинкскими решениями, пришлась на 1990-е годы, когда появилось ориентированное на миротворческую деятельность движение «Хельсинкская гражданская ассамблея». Ассамблея оказала определенное влияние, но не смогла сохраниться. Глобальная тенденция к «НПОизации» сместила акценты в правозащитной деятельности в сферу профессиональной работы в судах и защиты прав жертв нарушений, а авторитарные тенденции и ограничительная политика властей заставили большинство правозащитных групп перейти в оборонительный режим.

У правозащитников сегодня нет ощущения единого движения, стремящегося обойти возникшие в Европе разделительные линии. Они говорят на разных языках, поскольку у них разные приоритеты, в деятельности превалирует проектное мышление, а солидарность является скорее символической, а не реальной. Многие правозащитные группы, особенно на постсоветском пространстве, выражают разочарование низким уровнем солидарности, демонстрация которой зачастую ограничивается заявлениями, в которых выражается озабоченность, и документированием фактов нарушений прав человека в подробных отчетах, которые мало кто читает из-за их объема и профессионального жаргона. Хотя проводимые ОБСЕ форумы, такие как Совещание по рассмотрению выполнения обязательств в области человеческого измерения, открыты для участия гражданского общества, потенциальное влияние правозащитных групп сдерживается образом их мышления и действий - сосредоточенностью на конкретных проблемах, а не на предложении параллельных и альтернативных решений. Опираясь на историю хельсинкского движения и недавние примеры транснациональной деятельности, в данной статье подчеркивается необходимость более тесного трансграничного сотрудничества и взаимной поддержки. Связанные с ОБСЕ правозащитные группы должны выработать общий язык и повестку дня, отражающую стремление к большей справедливости и равенству в обществах на всем пространстве ОБСЕ, и способствовать формированию транснационального сообщества своих сторонников.

Статья начинается с обзора истоков хельсинкского движения и изменений, которые оно претерпело после распада Советского Союза. Затем дается критический анализ роли правозащитных групп, работающих бок о бок с институтами ОБСЕ. Рассмотрены примеры трансграничного сотрудничества, включая совместное реагирование на кризисы и общие усилия по восстановлению движения. В заключение предлагаются меры по укреплению и поддержке такого сотрудничества.

\section{Зарождение и трансформация движения}

В своей Нобелевской лекции 1975 г. физик и правозащитник Андрей Сахаров заявил, что мир, прогресс и права человека неразрывно связаны, и что нельзя достичь какой-либо одной из этих целей, пренебрегая двумя другими ${ }^{1}$. Международная 
безопасность, провозгласил он, немыслима без открытого общества со свободой информации, свободой совести, правом на публичное выражение мнений и свободой передвижения.

12 мая 1976 г. на пресс-конференции в квартире Сахарова было объявлено о создании Московской группы содействия выполнению хельсинкских соглашений, вскоре ставшей известной как Московская Хельсинкская группа (МХГ). Возглавляемая Юрием Орловым, выдвинувшим идею общественного контроля за соблюдением хельсинкского Заключительного акта, МХГ вдохновила развитие международного движения ${ }^{2}$. Основатели движения оказались в тюрьме или в изгнании, но хельсинкские группы и комитеты были созданы в других странах - сначала в бывших советских республиках, а затем и в западных государствах. Хельсинкская группа США, основанная при участии Людмилы Алексеевой - высланной из страны участницы изначальной МХГ, - впоследствии трансформировалась в Хьюман Райтс Уотч (Human Rights Watch).

Попытка преодолеть разделительные линии в Европе после падения берлинской стены породила новую волну хельсинкского движения, связанную с учреждением Хельсинкской гражданской ассамблеи (ХГА). ХГА стала форумом, на котором группы гражданского общества Востока и Запада могли обмениваться опытом, обсуждать общие проблемы и вырабатывать совместные стратегии ${ }^{3}$. Движущей силой движения была солидарность интеллектуалов Востока и Запада, которые стремились содействовать реализации инициатив гражданского общества в сложных регионах. В рамках этого движения были созданы группы в таких странах, как Армения, Азербайджан, Турция, Молдова и государства бывшей Югославии, в ряде которых возникли «замороженные» или «горячие» конфликты. В основном ХГА занималась вопросами мира и дипломатией между людьми, но некоторые группы занялись правозащитной деятельностью, став активными участниками национальных правозащитных сообществ в таких странах, как Армения и Турция. Однако в начале XXI в. это движение сошло на нет.

По мере того как все больше стран бывшего социалистического блока вступали в различные европейские организации большинство правозащитных групп перенесли акцент в своей деятельности либо на ЕС, либо на Совет Европы. ЕС использовал свое значительное финансовое и политическое влияние, а Европейский суд по правам человека (ЕСПЧ) вскоре стал одним из наиболее эффективных международных судебных механизмов для рассмотрения нарушений прав человека. Взаимодействие с этими организациями считалось предпочтительным вариантом, так как казалось, что оно с большей вероятностью приведет к долгосрочным демократическим переменам. В результате хельсинкские комитеты пошли разными путями. Одни из них предоставляли экспертные услуги на национальном уровне, сосредоточили свое внимание на судебных разбирательствах (в основном в ЕСПЧ) или работали над планами реформ, которые должны были приблизить вступление их стран в ЕС. 
Другие сосредоточили свою деятельность на урегулировании конфликтов и примирении на Балканах и на постсоветском пространстве.

Хотя большая часть групп сохранила в своем названии отсылку к Хельсинки, многие из них утратили связь с другими комитетами. Некоторые организации периодически проводили встречи, но совместные кампании стали редкостью. В конце 1990-х гг. Международная Хельсинкская Федерация, созданная в 1982 году в знак солидарности с советскими диссидентами, в поисках финансирования конкурировала с местными группами и уделяла намного больше внимания собственной организационной поддержке, чем своей миссии ${ }^{4}$. В 2008 году ее секретариат, располагавшийся в Вене, подал заявление о банкротстве после скандала, связанного с расхищением средств ее финансовым менеджером ${ }^{5}$.

Попытка оживить сотрудничество привела к созданию в 2010 г. Платформы гражданской солидарности. Платформа насчитывает 100 организаций-членов и выполняет важные функции координации их деятельности (включая совместный мониторинг и акции солидарности), поддержки формулирования заявлений по возникающим вызовам и общей координации взаимодействия с международными органами. Несмотря на многообещающее начало, эта организация стала жертвой тех же проблем, что и другие крупные международные НПО: зависимости от двустороннего финансирования, доминирования Запада, неэффективности механизмов принятия решений, а также легитимности, основанной лишь на репутации экспертов, а не на общественной поддержке. Взаимодействие большинства групп ограничивается участием в ежегодном собрании и подписанием публичных заявлений.

Реакция международного сообщества на кризисы в области прав человека малоэффективна и в основном ограничивается символическими жестами и выражением беспокойства. Соответственно, необходимо реформировать и укрепить движения за права человека, чтобы преодолеть вызовы авторитаризма, национализма и изоляционизма. В 2018 г., незадолго до своей смерти, на ежегодной конференции МХГ по проблемам прав человека Людмила Алексеева призывала партнеров: «Мы должны апеллировать к ценностям, историческому опыту и здравому смыслу. Это очень сложно, но необходимо и если мы будем убедительны, последовательны и тверды, то успех обязательно будет на нашей стороне. Поверьте, я знаю, о чем говорю. Когда мы начинали свой непростой путь в защиту прав человека, у нас было гораздо меньше поводов для оптимизма, чем сегодня, но мы верили в успех нашего безнадежного дела!»6.

\section{Примеры успешной мобилизации граждан}

Правозащитные группы предпринимали попытки искать альтернативные решения, основанные на практическом опыте реакций на правозащитные вызовы. Они предполагают формирование общего языка и повестки, направлены на расширение 
общественной поддержки идей прав человека и предлагают доступную широкой общественности программу действий. Правозащитная деятельность в основном все еще ограничивается освещением проблем и обращениями в суды и международные органы. Она также в значительной степени ориентирована на реализацию проектов и носит реактивный характер. Но есть и примеры успешных образовательных программ и мобилизации граждан. Подобные инициативы демонстрируют, как можно усилить правозащитную деятельность.

Один из таких примеров - международная Школа прав человека, созданная в 1990 г. Мареком Новицким из польского Хельсинкского фонда по правам человека. Образовательные программы фонда внесли большой вклад в формирование нового языка прав человека на русскоязычном постсоветском пространстве ${ }^{7}$. Слушатели Высших курсов по правам человека в Варшаве активно работают в различных организациях, а некоторые из них сами стали успешными тренерами по правам человека и правозащитной деятельности. Аналогичным образом Международная школа прав человека и гражданских действий (действовала с 2008 по 2020 год), организованная международным Молодежным правозащитным движением при поддержке МХГ, продолжила обучение нового поколения молодых правозащитников, многие из которых стали лидерами правозащитных групп как минимум в девяти странах. Эти образовательные инициативы способствовали распространению общего языка теории и практики обеспечения прав человека, создавая пространство для обмена опытом, тестирования новых идей, создания сетей и укрепления солидарности.

Еще один успешный пример движения, основанного на конкретном опыте реагирования, можно найти в Беларуси. В декабре 2010 г., когда начавшиеся после выборов в Беларуси протесты привели к насилию, российские и украинские правозащитники, у многих из которых был общий опыт участия в вышеупомянутых школах по правам человека, создали под эгидой Комитета международного контроля за ситуацией с правами человека в Беларуси $(\mathrm{KMK})^{8}$ Международную наблюдательную миссию (МНМ). Работая в Минске, МНМ осуществляла мониторинг ситуации и старалась обеспечить соблюдение принятых в рамках ОБСЕ обязательств. Она сосредоточила свою деятельность на защите преследуемых журналистов, юристов и правозащитников, наблюдала за обысками и судебными процессами, находилась в постоянном контакте с местными группами и информировала соответствующие органы ОБСЕ и ООН. В течение нескольких месяцев КМК работал без внешнего финансирования. Тем не менее ему удалось привлечь $43 \mathrm{HКО,} \mathrm{вовлечь} \mathrm{в} \mathrm{свою} \mathrm{рабо-}$ ту более 75 человек и повлиять на принимавшиеся в то время основные решения по Беларуси, в том числе о задействовании «московского механизма» ОБСЕ, а также на ряд резолюций ООН и Совета Европы. На символическом уровне КМК привлек дополнительное внимание к проблеме прав человека в Беларуси в таких странах, как Россия и Украина. Он способствовал укреплению международной солидарности и создал модель реагирования гражданского общества на репрессии, основанную на конкретных фактах, с опорой на региональный опыт и при сохранении междуна- 
родных связей9. Наконец, Комитет учредил должность Специального докладчика и подключил к расследованию событий 19 декабря 2010 г. Нила Джармана, председателя Группы экспертов Бюро по демократическим институтам и правам человека (БДИПЧ) ОБСЕ по вопросам свободы собраний ${ }^{10}$. Специальный докладчик изучил события на улицах Минска, которые правительство называло массовыми беспорядками, и сформулировал адресованные властям вопросы. Представленный им отчет, основанный на этих вопросах и других общедоступных данных, предшествовал официальному отчету, подготовленному в рамках «московского механизма» ОБСЕ, который частично опирался на выводы Специального докладчика и констатировал грубые и систематические нарушения прав человека ${ }^{11}$. Что особенно важно, КМК и МНМ продемонстрировали возможности трансграничного взаимодействия и солидарности, а также поддержки правозащитников на местах, который может служить примером для деятельности по осуществлению общественного контроля за действиями властей во время массовых нарушений прав человека.

Другая модель мобилизации граждан - инициативы независимых наблюдателей России, Украины и Беларуси. Такие инициативы в основном направлены на мониторинг судебных процессов (например, посещение судебных заседаний в целях контроля доступности и открытости судов для общественности), обеспечение общественного контроля за правоохранительной деятельностью (путем регулярных проверок полицейских участков и работы полицейских патрулей) и мониторинг массовых митингов. На этой основе сформировалось международное движение независимых наблюдателей, которые иногда участвуют также в деятельности по медиации и предотвращению конфликтных ситуаций. Данные инициативы опираются в своей деятельности на обязательства в области прав человека, собранные в Руководящих принципах БДИПЧ ОБСЕ и Венецианской комиссии по свободе мирных собраний, на методы, включенные в Руководство БДИПЧ ОБСЕ по мониторингу свободы мирных собраний и Руководство по мониторингу судебных процессов, распространяя информацию о соответствующих обязательствах и методах среди наблюдателей-волонтеров, участвующих в движении гражданского контроля ${ }^{12}$.

Мобилизация граждан дополняет осуществляемый БДИПЧ официальный мониторинг, в котором участвуют только сотрудники Бюро и пул отобранных международных экспертов. Мониторинг по линии БДИПЧ требует значительных ресурсов и зависит от готовности властей допустить наблюдателей, что делает их присутствие в некоторых странах практически невозможным. Гражданские группы способны освещать крупные массовые протесты и ключевые судебные процессы там, куда официальные наблюдатели ОБСЕ не имеют доступа, и в таком количестве, которое БДИПЧ не может обеспечить. Они также работают в первую очередь с внутренней аудиторией, представляя своему обществу факты и сопоставляя их с международными стандартами, принятыми их странами. Самое главное, они служат опорными точками для мобилизации более широкого участия граждан. 


\section{Укрепление правозащитных движений}

Одна из основных целей правозащитных групп - обеспечить подотчетность обществу режимов, грубо нарушающих права человека. Чтобы достичь этой цели, такие группы должны заниматься решением ключевых социальных проблем и создавать гражданские правозащитные движения. Для этого им необходима благоприятная среда, достаточное количество сторонников, разбирающихся в вопросах прав человека, экономическая устойчивость и финансовая независимость.

Существуют определенные группы, которые работают на переднем крае защиты прав человека. К ним относятся журналисты, которые информируют общество и формируют повестку дня общественных дискуссий, адвокаты, которые должны иметь возможность защищать обвиняемых, не опасаясь обвинения в причастности к якобы совершенным их клиентами преступлениям и судебного преследования, и правозащитники, которые должны иметь возможность защищать права других и быть признаны выполняющими ключевую функцию по восстановлению справедливости в отношении жертв нарушений и обеспечению соблюдения международных обязательств в области прав человека. Не случайно эти группы становятся мишенью во время оспариваемых выборов или массовых беспорядков.

Можно утверждать, что преследование представителей любой из этих групп не внутренний вопрос или незначительное нарушение, а угроза для всей международной системы защиты прав человека. Однако в открытом доступе нет списка представителей таких групп, которые были осуждены на тюремные сроки или иным образом подвергаются преследованию за свою профессиональную деятельность. Более того, если не считать пресловутые заявления с выражением обеспокоенности, похоже, что до настоящего времени по линии международных организаций не предпринимались какие-либо скоординированные действия для того, чтобы добиться их освобождения ${ }^{13}$. БДИПЧ ранее занималось, в частности, мониторингом ситуации с правозащитниками, но имело возможность осуществлять эту деятельность лишь в немногих государствах-участниках ${ }^{14}$. ОБСЕ - одна из немногих организаций, в документах которой говорится о дополнительных гарантиях свободы передвижения правозащитников и журналистов ${ }^{15}$.

В целом же ощущается нехватка целевой и ориентированной на практическую деятельность подготовки в области прав человека, а также деятельности по повышению осведомленности широкой общественности, которая не ограничивалась бы узким кругом единомышленников. В предлагаемых в рамках системы высшего образования учебных программах по правам человека обычно не затрагиваются вопросы практической деятельности по их защите. Программы высшего образования редко предусматривают взаимодействие с активными правозащитниками (например, возможность прохождения стажировки в правозащитных организациях), что приводит к отрыву учебного процесса от практики. Это препятствует проведению исследований в области прав человека в наиболее проблемных странах. Ощущается также 
явная нехватка образовательных курсов, которые опирались бы как на местный, так и на международный контекст, к которым привлекались бы специалисты с опытом работы на местах и которые были бы доступны на русском и национальных языках государств-участников ОБСЕ как онлайн, так и офлайн. В большей степени ориентированная на практику подготовка в области прав человека способствовала бы лучшему пониманию ситуации на местах и повышению осведомленности общественности о правах человека. Помимо этого для укрепления работы правозащитных групп необходимо продвижение ценностей прав человека и роли правозащитников. Для этой цели легко могут быть адаптированы маркетинговые методы, используемые в коммерческом секторе. Таким методам коммуникации уделяется сейчас все больше внимания, и некоторые примеры из практики правозащитных групп вдохновляют ${ }^{16}$.

Наконец, финансирование правозащитной деятельности часто затруднено из-за преобладания проектного подхода, зависимости от приоритетов стран-доноров или фондов и отсутствия долгосрочных инвестиционных моделей. Фонд целевого капитала («эндаумент») Московской Хельсинкской группы - единственный на постсоветском пространстве пример создания важного и устойчивого источника средств в секторе прав человека (подобного тем, какими пользуются университеты и другие общественные учреждения) и поддержки долгосрочных инвестиций в правозащитную деятельность ${ }^{17}$. Появление фондов местных сообществ также представляет собой серьезный сдвиг в плане общественной филантропии, который может оживить правозащитное движение ${ }^{18}$. Хотя социально ответственное инвестирование становится все более популярным среди частных инвесторов, единственная правозащитная группа, которая, похоже, развивает это направление, - Международная федерация за права человека (МФПЧ), создавшая собственный этический инвестиционный фонд «Свобода и солидарность» (Libertés \& Solidarité), который при выборе акций исходит из основанных на принципе прав человека критериев и использует механизм разделения прибыли между МФПЧ и инвесторами ${ }^{19}$. Необходимы дальнейшие шаги для внедрения подобных практик в более широком правозащитном сообществе. Они открывают возможности как для привлечения пожертвований крупных институциональных доноров, так и для международных краудфандинговых кампаний, которые могут проводиться параллельно с кампаниями по повышению осведомленности. Разнообразное финансирование дает гораздо больше возможностей для экспериментов, инноваций, проб и ошибок. Поэтому повышение разнообразия источников финансирования и экономической устойчивости, выстраивание альтернативных финансовых моделей и укрепление финансовой независимости сектора позволят сделать работу правозащитных организаций более гибкой и стратегической ${ }^{20}$.

Уделение большего внимания этим вопросам откроет возможности для реализации более широких инициатив, выходящих за рамки обычной, ориентированной на проекты логики работы НПО. Это позволит правозащитным группам продолжать 
свою работу на местах, опираясь на широкую общественную поддержку и оставаясь частью международного движения. В конце концов, именно в этом и заключалась суть хельсинкского движения: постоянное напоминание о том, что вопросы человеческого измерения безопасности - это не просто предмет межгосударственных переговоров, а вопросы, актуальные для более широкого движения гражданского общества.

\section{Рекомендации}

Нижеследующие рекомендации представляют собой обращенное к работающим в регионе ОБСЕ организациям по правам человека предложение сосредоточиться на общих приоритетах. Эти организации могли бы обратиться к институтам и заинтересованным государствам-участникам ОБСЕ с призывом:

1. Предоставить поддержку, защиту и создать благоприятную среду для работы журналистов, адвокатов и правозащитников, в частности, путем:

a) согласования, составления и обнародования имеющихся списков представителей этих групп, которые были подвергнуты тюремному заключению или иным преследованиям за свою профессиональную деятельность, а также координации общих действий, направленных на то, чтобы добиться их освобождения, если они находятся в тюрьме;

б) разработки мер, которые могут быть применены в случаях, когда представители вышеуказанных категорий сталкиваются с репрессиями, вызванными непосредственной работой с органами ОБСЕ. Примером для ОБСЕ могут послужить механизмы противодействия подобным репрессиям, существующие в Совете Европы и ООН;

в) содействия транснациональному сотрудничеству организаций гражданского общества, особенно в сфере прав человека;

г) предоставления политической, финансовой и экспертной поддержки международным институтам, которые занимаются такими группами, включая персонал, владеющий соответствующими языками и знающий страны, в которых данные группы сталкиваются с наибольшими проблемами;

д) организации встречи представителей заинтересованных государств и экспертов гражданского общества, во-первых, для классификации преследований журналистов, адвокатов и правозащитников как вопиющего пренебрежения обязательствами ОБСЕ и угрозы всеобъемлющей безопасности и, во-вторых, для обсуждения путей для противодействия такому преследованию и исправления ситуации. 
2. Содействовать расширению круга сторонников и последователей правозащитных групп, в том числе пощщяя профильное образование в области прав человека, в частности, путем:

a) подключения агентств по связям с общественностью и рекламных агентств, с тем чтобы помочь активистам правозащитного движения сформулировать и оформить свои послания, привлечь больше последователей и создать сообщества поддержки;

б) обусловить поддержку программ высшего образования, ориентированных на права человека, обязательным активным участием правозащитников-практиков и поощрять стажировки в правозащитных организациях;

в) поощрения международных академических обменов в области прав человека, в том числе стажировок и совместных проектов;

г) инвестирования в масштабные образовательные курсы для широкой аудитории (доступные онлайн и офлайн), в которых концепции и стандарты прав человека разъяснялись бы на всех официальных языках ОБСЕ и которые были бы дополнены ориентированными на практическую деятельность аспектами, такими как методы гражданского контроля;

д) подготовки новой когорты просветителей в области прав человека, которые могли бы стать мультипликаторами знаний, устанавливать и поддерживать связи и сетевые отношения как на местном, так и на международном уровне.

3. Провести переоценку экономической устойчивости и финансовой независимости сектора прав человека. Хотя в некоторых государствах могут возрасти риски, связанные с иностранным финансированием, с этим следует бороться не путем отказа от поддержки, а путем поиска других способов ее оказания, в том числе непосредственно гражданами. Транснациональные связи в этом контексте должны поощряться. Поэтому следует рассмотреть следующие шаги:

а) поощрять развитие различных финансовых моделей и инвестиционных систем в интересах правозащитной деятельности, включая пожертвования, фонды местных сообществ, социально ответственные инвестиции и краудфандинговые платформы;

б) сделать приоритетом мобилизацию внутреннего финансирования и поддержки, одновременно отстаивая право на получение международного финансирования для осуществления деятельности в области прав человека. 


\section{Приложение. Список хельсинкских групп и комитетов}

\begin{tabular}{|c|c|c|c|}
\hline Название в 2021 г. & \begin{tabular}{|l|} 
Название при создании \\
(если изменилось)
\end{tabular} & Год создания & Адрес сайта \\
\hline $\begin{array}{l}\text { Албания: Албанский Хельсинк- } \\
\text { ский комитет }\end{array}$ & $\begin{array}{l}\text { Албанский форум защиты } \\
\text { основных прав и свобод че- } \\
\text { ловека }\end{array}$ & 1990 & https://ahc.org.al/ \\
\hline $\begin{array}{l}\text { Армения: Хельсинкский коми- } \\
\text { тет Армении }\end{array}$ & & 1996 & http://armhels.com/ \\
\hline $\begin{array}{l}\text { Армения: Хельсинкская граж- } \\
\text { данская ассамблея - Армения }\end{array}$ & & 1992 & \\
\hline $\begin{array}{l}\text { Армения: Хельсинкская граж- } \\
\text { данская ассамблея — Ванадзор }\end{array}$ & & 1998 & https://hcav.am/en/ \\
\hline $\begin{array}{l}\text { Армения: Хельсинкская ассоци- } \\
\text { ация Армении }\end{array}$ & & 1997 & https://hahr.am/ \\
\hline $\begin{array}{l}\text { Австрия: Австрийская Хель- } \\
\text { синкская ассоциация }\end{array}$ & & 2008 & http://austrianhelsinki.at/ \\
\hline $\begin{array}{l}\text { Азербайджан: Хельсинкская } \\
\text { гражданская ассамблея - Азер- } \\
\text { байджан }\end{array}$ & & 1992 & \\
\hline $\begin{array}{l}\text { Беларусь: Белорусский Хель- } \\
\text { синкский комитет }\end{array}$ & & 1995 & https://www.belhelcom.org/ \\
\hline $\begin{array}{l}\text { Босния и Герцеговина: Хель- } \\
\text { синкская гражданская ассам- } \\
\text { блея Баня-Лука }\end{array}$ & & 1996 & http://hcabl.org/ \\
\hline $\begin{array}{l}\text { Босния и Герцеговина: Хель- } \\
\text { синкский комитет по правам че- } \\
\text { ловека в Боснии и Герцеговине }\end{array}$ & & 1995 & \\
\hline $\begin{array}{l}\text { Болгария: Болгарский Хель- } \\
\text { синкский комитет }\end{array}$ & & 1992 & https://www.bghelsinki.org \\
\hline $\begin{array}{l}\text { Канада: Канадская Хельсинк- } \\
\text { ская наблюдательная группа* }\end{array}$ & & 1985 & \\
\hline $\begin{array}{l}\text { Хорватия: Хорватский Хель- } \\
\text { синкский комитет по правам че- } \\
\text { ловека }\end{array}$ & & 1993 & http://www.hho.hr/ \\
\hline $\begin{array}{l}\text { Чехия: Чешский Хельсинкский } \\
\text { комитет }\end{array}$ & $\begin{array}{l}\text { Чехословацкий Хельсинк- } \\
\text { ский комитет }\end{array}$ & 1988 & http://www.helcom.cz/ \\
\hline $\begin{array}{l}\text { Дания: Датский Хельсинкский } \\
\text { комитет по правам человека }\end{array}$ & & 1985 & http://helsinkicommittee.dk \\
\hline $\begin{array}{l}\text { Франция: Европейская ассам- } \\
\text { блея граждан }\end{array}$ & & 1990 & http://www.aechca.fr/ \\
\hline $\begin{array}{l}\text { Грузия: Грузинский Хельсинк- } \\
\text { ский комитет * }\end{array}$ & & 1976-1977 & \\
\hline $\begin{array}{l}\text { Германия: Германский Хель- } \\
\text { синкский комитет по правам че- } \\
\text { ловека, безопасности и сотруд- } \\
\text { ничеству в Европе* }\end{array}$ & & & \\
\hline
\end{tabular}




\begin{tabular}{|c|c|c|c|}
\hline Название в 2021 г. & \begin{tabular}{|l} 
Название при создании \\
(если изменилось)
\end{tabular} & Год создания & Адрес сайта \\
\hline $\begin{array}{l}\text { Греция: Греческая группа по } \\
\text { наблюдению за выполнением } \\
\text { хельсинкских соглашений }\end{array}$ & & 1993 & $\begin{array}{l}\text { https://greekhelsinki.wordpre } \\
\text { ss.com/ }\end{array}$ \\
\hline $\begin{array}{l}\text { Венгрия: Венгерский Хельсинк- } \\
\text { ский комитет }\end{array}$ & & 1989 & https://helsinki.hu/ \\
\hline $\begin{array}{l}\text { Италия: Итальянская федерация } \\
\text { прав человека - Итальянский } \\
\text { Хельсинкский комитет }\end{array}$ & & 1987 & https://fidu.it/ \\
\hline $\begin{array}{l}\text { Казахстан: Алматинский Хель- } \\
\text { синкский комитет * }\end{array}$ & & 1990 & \\
\hline \multicolumn{4}{|l|}{$\begin{array}{l}\text { Косово: Косовский Хельсинк- } \\
\text { ский комитет * }\end{array}$} \\
\hline $\begin{array}{l}\text { Литва: Литовская Хельсинкская } \\
\text { группа* }\end{array}$ & & $\begin{array}{l}\text { 1976-1983, вос- } \\
\text { создана в } 1988\end{array}$ & \\
\hline $\begin{array}{l}\text { Молдова: Молдавский Хель- } \\
\text { синкский комитет по правам че- } \\
\text { ловека * }\end{array}$ & & 1992 & \\
\hline \multicolumn{4}{|l|}{$\begin{array}{l}\text { Молдавия: Хельсинкская ассам- } \\
\text { блея граждан - Молдавия* }\end{array}$} \\
\hline \multicolumn{4}{|l|}{$\begin{array}{l}\text { Черногория: Хельсинкский ко- } \\
\text { митет по правам человека в } \\
\text { Черногории }\end{array}$} \\
\hline $\begin{array}{l}\text { Норвегия: Норвежский Хель- } \\
\text { синкский комитет }\end{array}$ & & 1977 & https://www.nhc.no/ \\
\hline $\begin{array}{l}\text { Северная Македония: Хель- } \\
\text { синкский комитет по правам че- } \\
\text { ловека }\end{array}$ & & 1994 & https://mhc.org.mk/ \\
\hline $\begin{array}{l}\text { Нидерланды: Нидерландский } \\
\text { Хельсинкский комитет }\end{array}$ & & 1987 & https://www.nhc.nl/ \\
\hline $\begin{array}{l}\text { Румыния: Ассоциация по защи- } \\
\text { те прав человека в Румынии - } \\
\text { Хельсинкский комитет }\end{array}$ & & 1990 & https://apador.org/ \\
\hline $\begin{array}{l}\text { Польша: Польский Хельсинк- } \\
\text { ский комитет и Хельсинкский } \\
\text { Фонд по правам человека }\end{array}$ & $\begin{array}{l}\text { Хельсинкский комитет в } \\
\text { Польше }\end{array}$ & $\begin{array}{l}\text { 1982, под совре- } \\
\text { менным назва- } \\
\text { нием известен с } \\
1989\end{array}$ & https://www.hfhr.pl/ \\
\hline $\begin{array}{l}\text { Россия: Московская Хельсинк- } \\
\text { ская группа }\end{array}$ & & $\begin{array}{l}\text { 1976, воссозда- } \\
\text { на в } 1989\end{array}$ & https://mhg.ru/ \\
\hline $\begin{array}{l}\text { Сербия: Хельсинкский комитет } \\
\text { по правам человека Сербии }\end{array}$ & & 1994 & http://www.helsinki.org.rs/ \\
\hline $\begin{array}{l}\text { Словакия: Хельсинкский коми- } \\
\text { тет по правам человека Слова- } \\
\text { кии }\end{array}$ & & 1993 & https://www.helcom.sk/ \\
\hline $\begin{array}{l}\text { Словения: Словенский Хель- } \\
\text { синкский монитор* }\end{array}$ & & 1994 & \\
\hline
\end{tabular}




\begin{tabular}{|c|c|c|c|}
\hline Название в 2021 г. & $\begin{array}{l}\text { Название при создании } \\
\text { (если изменилось) }\end{array}$ & Год создания & Адрес сайта \\
\hline $\begin{array}{l}\text { Испания: Хельсинки Испания } \\
\text { — человеческое измерение }\end{array}$ & & 1992 & helsinkiespana.org \\
\hline $\begin{array}{l}\text { Швеция: Защитники граждан- } \\
\text { ских прав }\end{array}$ & $\begin{array}{l}\text { Шведский Хельсинкский } \\
\text { комитет }\end{array}$ & 1982 & https://crd.org/ \\
\hline $\begin{array}{l}\text { Швейцария: Швейцарский } \\
\text { Хельсинкский комитет }\end{array}$ & & 1977 & https://shv-ch.org/ \\
\hline $\begin{array}{l}\text { Турция: Хельсинкская ассам- } \\
\text { блея граждан }\end{array}$ & & 1990 & https://hyd.org.tr/ \\
\hline $\begin{array}{l}\text { Украина: Украинский Хель- } \\
\text { синкский союз по правам чело- } \\
\text { века }\end{array}$ & $\begin{array}{l}\text { Украинская Хельсинкская } \\
\text { группа }\end{array}$ & $\begin{array}{l}\text { 1976-1981, вос- } \\
\text { создан в } 2004 \\
\text { как Украинский } \\
\text { Хельсинкский } \\
\text { союз по правам } \\
\text { человека }\end{array}$ & https://helsinki.org.ua/ \\
\hline $\begin{array}{l}\text { Украина: Международная хель- } \\
\text { синкская ассоциация по правам } \\
\text { человека }\end{array}$ & & 2011 & https://ihahr.org/ \\
\hline $\begin{array}{l}\text { США: Хьюман Райтс Уотч } \\
\text { (Human Rights Watch) }\end{array}$ & Helsinki Watch & 1978 & https://www.hrw.org/ \\
\hline
\end{tabular}

* Группы, которые больше не активны или по которым нет информации об их деятельности.

\section{Примечания}

1 Сахаров А. Мир, прогресс, права человека. Нобелевская лекция, 11 декабря 1975 // Тhe Nobel Prize. URL: https://www.nobelprize.org/prizes/peace/1975/sakharov/26035-andrei-sakhar ov-nobel-lecture-1975/.

2 См.: Snyder S. B. Human Rights Activism and the End of the Cold War: A Transnational History of the Helsinki Network. - New York: Cambridge University Press, 2011; Goldberg P. The Final Act: The Dramatic, Revealing Story of the Moscow Helsinki Watch Group. - New York: William Morrow \& Company, 1988.

3 Schennink B. Helsinki from Below: Origin and Development of the Helsinki Citizens' Assembly (HCA) // OSCE Yearbook 1997 / IFSH. - Baden-Baden: Nomos, 1998. P. 403-415.

4 См.: Rhodes A. The Continuing Challenge of the International Helsinki Federation for Human Rights (IHF) // OSCE Yearbook 1995/1996 / IFSH. - Baden-Baden: Nomos, 1997. P. 401-410.

5 Bigg C. Helsinki Federation shuts down after fraud scandal // Radio Free Europe/Radio Liberty. 2007. 12 December. URL: https://www.rferl.org/a/1079257.html.

6 Алексеева Л. Бескомпромиссно защищать жертв и стоять друг за друга // Новая газета. 2018. 9 декабря. URL: https://novayagazeta.ru/articles/2018/12/09/78875-beskompromissno-zas chischat-zhertv-i-drug-druga.

7 Сайт Польского Хельсинкского фонда прав человека. URL: https://www.hfhr.pl/dzialania/ed ukacja-miedzynarodowa/.

8 Комитет международного контроля за ситуацией с правами человека в Беларуси. URL: https://hrwatch-by.org/en. 
9 Баранов К., Объездчикова А. Комитет международного контроля за ситуацией с правами человека в Республике Беларусь как пример комплексной тактики защиты прав человека на пост-советском пространстве. - Воронеж: Артефакт, 2012.

10 Меморандум о назначении Специального Докладчика по событиям 19 декабря 2010 года. Комитет международного контроля за ситуацией с правами человека в Беларуси. URL: https:/hrwatch-by.org/sites/default/files/BYC\%20-\%20SR\%20memorandum\%20-\%20RUS.pdf.

11 OSCE Rapporteur's Report on Belarus. By prof. Emmanuel Decaux. ODIHR.GAL/39/11/ Corr.1*, 16 June 2011 // Официальный сайт ОБСЕ. URL: https://www.osce.org/files/f/ documents/6/b/78705.pdf; Специальный докладчик по событиям 19 декабря 2010 г. Итоговая оценка событий 19 декабря 2010 года в Минске, Беларусь, с точки зрения прав человека. URL: https://protivpytok.org/wp-content/uploads/2012/01/Final_HRights_Assessment_of_19-12-2010_in_Minsk-rus_final_copy.pdf.

12 Руководящие принципы по свободе мирных собраний. Издание 2-е. - Варшава: БДИПЧ ОБСЕ, 2011. URL: https://www.osce.org/files/f/documents/d/6/83237.pdf; Руководство по мониторингу свободы мирных собраний. - Варшава: БДИПЧ ОБСЕ, 2011. URL: https://www.osce.org/files/f/documents/a/4/82987.pdf; Мониторинг судебных процессов: Справочное руководство для практиков. - Варшава: БДИПЧ ОБСЕ, 2008. URL: https://www.osce.org/files/f/documents/6/d/31637.pdf; Руководство по мониторингу административной юстиции. - Варшава: БДИПЧ ОБСЕ, 2013. URL: https:/www.osce.org/files/f/ documents/5/6/108280.pdf.

13 Организация Международная амнистия (Amnesty International) несколько шире определяет понятие «узник совести», включая в него тех, кто находится в заключении из-за того, кем они являются или во что верят. Несколько групп регулярно обновляют списки «политических заключенных» (так, по данным правозащитного центра «Вясна», только в Беларуси по состоянию на 6 декабря 2021 г. их насчитывалось 907 человек). См.: https://pri soners.spring96.org/en.

14 См.: Правозащитники в регионе ОБСЕ: Наша коллективная совесть. - Варшава: БДИПЧ ОБСЕ, 2007. URL: https://www.osce.org/files/f/documents/b/f/29715.pdf; The Situation of Human Rights Defenders in Selected OSCE Participating States. The Final Report of the First Assessment Cycle (2017-2019). - Warsaw: OSCE ODIHR, 2021. URL: https://www.osce.org/o dihr/493867.

15 См.: Вашкевич А. Стандарты ОБСЕ // Трансграничные аспекты свободы передвижения: международные стандарты и практические проблемы на примере Беларуси, России и Украины / под ред. К. Баранова, А. Казлюка. - Львов: Лига-Пресс, 2015. С. 44-60.

16 См., в частности: "Human Rights Communication 2.0". Agenda. Akvarium Klub, Budapest, Hungary, 5 December 2017. URL: https:/www.osce.org/odihr/human-rights-communications-2 .0. См. также кампанию Болгарского хельсинкского комитета «Для людей». URL: https://w ww.bghelsinki.org/en/campaigns/bhc-for-the-people. Другими примерами могут служить эксперименты с игровыми инновациями, проводимые российским некоммерческим сектором. См., в частности: Толстенева Т. Технологические и игровые инновации дают новую жизнь российским НКО // OpenGlobalRights. 2019. 12 September. URL: https://www.openglobalrights.org/technology-and-gaming-innovations-bring-new-life-to-russian-ngos/?lang=Russian, a также интерактивный мини-сериал с молодыми активистами правозащитного движения в главных ролях - совместный проект студии Lateral Summer, Московской Хельсинкской группы и «Новой газеты». URL: https://lateralsummer.ru/,

17 Фонд Московской Хельсинкской группы. URL: https://endowment.mhg.ru/.

18 См.: Community Philanthropy and \#ShiftThePower // The Global Fund for Community Foundations. URL: https://globalfundcommunityfoundations.org/what-we-stand-for/shiftthepower/. 
19 См.: International Federation for Human Rights. URL: https://www.fidh.org/fr/com/faire-un-don /faire-un-placement-solidaire-6650.

20 Анализ различных финансовых моделей см. в отчете Инициативы по правам человека Центра стратегических и международных исследований: Rekosh E. Rethinking the Human Rights Business Model: New and Innovative Structures and Strategies for Local Impact // Center for Strategic \& International Studies. 2017. 14 June. URL: https://www.csis.org/analysis/rethinki ng-human-rights-business-model. 
